\title{
REFORMING LAW ON ADMINISTRATIVE PROCEDURES TOWARDS A RULE-OF-LAW STATE IN VIETNAM
}

\section{Background of administrative procedures reform in Vietnam}

Vietnam has embarked on the open market economy under socialist orientation since the amendment of the 1980 Constitution in 1992 due to the collapse of the former Soviet Union. The introduction of Doimoi (renovation) in 1986 is considered as a turning point of Vietnam. Doimoi required government to change its role in order to meet the growing demands. It is the same as the case of China, 'the transitional to market economy required a new form of government and style of regulation.' ${ }^{1}$ Vietnamese Government could not carry out both economic and public administrative functions as used to be in the period of centrally planned economy. It other words, the role of government in transition has changed from government-controlled to government-steered in the market-based system. As the centrally planned economy created the 'applicationapproval' administrative system, therefore, it was essential to reform administrative system in order to respond to the changes of economic regime. In addition, global integration also requires Vietnam to reform public sector to achieve development targets. 'Institutional reform, human resources development, recourse mobilization and financial management, and innovation and information technology capacity building' are essential reforms to integrate into the global economy and achieve the MDGs.' ${ }^{2}$

Public administrative reforms (PAR) were carried out since 1990s to meet the demands of market economy with the major focus on rationalizing the legal and regulatory frameworks of the government system, reforming the machinery of the public administrative system at all levels as well as administrative procedures. Vietnam has carried out administrative reform through developing two master plans for administrative reform during the period 2000-2010 and 2011-2020. It is evidenced

1 L. Dittmer, Guoli Liu, China's Deep Reform: Domestic Politics in Transition, Rowman \& Littlefield, Lanham, Maryland 2006, p. 194.

2 Reinventing Government for the Twenty-First Century: State Capacity in a Globalizing Society, eds. D.A. Rondinelli, G. Shabbir Cheema, Kumarian Press 2003, p. 26. 
that Vietnam is still struggling to build up a democratic society in the era of integration and globalization.

The reform of administrative procedures is one of the most important objectives of the Master Plan for the 2011-2020 period: 'To create an equal, open, favorable and transparent business environment to reduce time and costs for enterprises of all economic sectors in compliance with the administrative procedures.' ${ }^{3}$ The reform of administrative procedures is urgent need of Vietnamese government to promote economic development. Especially, the 2013 Constitution in 2013 requires elimination of administrative procedures that are obstacles to exercise the rights of individuals/organizations towards rule-by-law state and democratic society.

To simplify administrative procedures is one of the important tasks of Vietnamese government. Significantly, Government issued Decision No. 93/2007/ QD-T'Tg of June 22, 2007, promulgating the Regulation on implementation of the one-stop-shop and inter-agency one-stop-shop mechanisms at local state administrative agencies and Decision No. 09/2015/QĐ-TTg amending the Decision No. 93/2007. According to these Decisions, one-stop-shop model aims at reforming 'the way of handling affairs of individuals or organizations which fall under the responsibility and jurisdiction of a single state administrative agency in publicizing and guiding administrative procedures, receiving dossiers, handling affairs and delivering results, which shall be carried out at a focal point being the dossier-receiving and result-delivering section of the state administrative agency.' (Article 1.1, Decision No. 09/2015). Consequently, one-stop-shop model was established at provincial level for receiving and handling affairs of individuals or organizations, for example the Administrative Center of Da Nang Province, or Administrative Center of Quang Ninh Province including different specialized agencies such as Department of Investment, Department of Construction, Department of Education and Training; Department of Financial, Department of Planning and Investment; Department of Labor, Invalid and Social Affairs which enable individuals and organizations to implement their rights effectively.

In addition, Vietnamese government also recognizes that e-government is the way of simplifying administrative procedures. E-government is not only the way of using technology in public administration but also the way of providing public services to citizens and ensuring transparency. ${ }^{4}$ In regard to the application of E-government, Government's Resolution No. 26/NQ-CP dated April 15, 2015 has issued the Government's Program of Action for implementation of the Resolution No. 36-NQ/TW dated July 1, 2014 of the Politburo of the Central Committee of

3 Resolution No. 30c/NĐ-CP on Master Program on Administrative Reform in the 20112020 period, dated November 8, 2011, Article 2.2

4 Sodhi Singh Inderjeet, Trends, Prospects, and Challenges in Asian E-Governance, IGI Global 2015, p. 42. 
the Communist Party on promoting the application and development of information technology to meet sustainable development and international integration requirements, and Resolution No. 17/NQ-CP dated March 7, 2019. The situation of E-government was reviewed under Resolution No. 17 as follows: 'The ministries, sectoral administrations and localities have made great efforts and achieved initial results in developing the e-Government, including: promulgating, within its competence, and appealing to competent authorities to promulgate regulations and guidelines for improving the regulatory framework and enhancing the construction of the e-Government; building, commissioning and operating the National Database of Enterprise Registration, step-by-step building the National Database of Insurance, the National Database of Land and the National Database of Population; having already provided a few essential online public services for businesses and people, e.g.: enterprise registration, tax declaration, tax payment, customs, social insurance, etc.; a number of ministries and sectoral administrations have processed files in the networked environment. ${ }^{5}$

According to the United Nations' e-Government Assessment Report in 2018, Vietnam's e-Government Development Index ranked 88 out of 183 countries, moved up 1 place, including the online service component index (OSI) rose by 15 spots to the $59^{\text {th }}$ rank in 193 countries. ${ }^{6}$ However, there is no single regulation that governs all aspects of public administration. E-government program faces some issues and challenges such as the lack of the leader's roles in providing directions and guidelines for performing tasks; the effective guarantee mechanism for the implementation of the tasks of building e-Government; a lack of a consistent legal framework on building e-Government; a lack of financial and investment mechanisms suitable to specific information technology projects; a lack of specific regulations on identification and authentication of individuals and organizations in electronic transactions; a lack of legislative regulations on electronic documents and archives (Resolution No. 17/2019).

Particularly, administrative procedures lack transparency and they do not ensure the accountability of authorities. Time-consuming and complicated procedures to obtain substantive licenses and documents without comprehensive and consistent regulations are the main issues of administrative procedures in Vietnam. For example, there are around 5 thousand to 7 thousand different licenses which may apply to enterprises doing business in Vietnam. ${ }^{7}$ Government and administrative regula-

5 Resolution No. 17/NQ-CP on certain key tasks and measures of development of the electronic government for the period 2019-2020 with vision towards 2025 dated March 7, 2019.

${ }^{6}$ https://publicadministration.un.org/egovkb/Portals/egovkb/Documents/un/2018-Survey/E-Government $\% 20$ Survey\%202018_FINAL\%20for\%20web.pdf (accessed: 11.11.2019).

7 Bỏ "giấy phép con", vẫn chuia giải quyết gốc vấn đề, https://tuoitre.vn/bo-giay-phep-con-van-chua-giai-quyet-goc-van-de-1394464.htm (accessed: 6.10.2019). 
tions' burden accounts for $22 \%$ of barriers to social enterprise growth. ${ }^{8}$ Vietnam needs to cut off $50 \%$ of business and administrative procedures in order to reach global institutional standards. ${ }^{9}$

In addition, citizen's right to participate in formulation of administrative procedures is still limited. Although, the assessment of regulation's impact of administrative procedures is compulsory procedure in process of promulgating status laws and substantive laws (Decrees, Circulars, Decisions) however reforming and simplifying administrative procedures is still an urgent task of Vietnamese government. ${ }^{10}$ Significantly, currently Government issued Resolution No. 02/2019/NQ-CP on ongoing implementation of major duties and measures to improve business environment and enhance national competitiveness by 2019 and vision towards 2021. This resolution identifies that: "Thousands of irrational business requirements have been annulled; Vietnam has not joint top 4 leading countries of ASEAN region (business environment index is ranked $5^{\text {th }}$ place and national competitiveness is ranked $7^{\text {th }}$ place). ${ }^{11}$ These issues resulted from the lack of comprehensive legal framework on administrative procedures which will be analyzed in the second part of this paper.

\section{Current legal framework on administrative procedures in Vietnam: issues and challenges}

Law on administrative procedures is very important for exercising the rights as well as controlling corruption, creating an accountable and transparent administrative system. However, the current legal framework on administrative procedures includes many legal documents which cause many issues and challenges preventing Vietnam from building democratic and rule-of-law society as well as reaching the good governance standards as follows:

1. Administrative procedures are inconsistent and overlapped. Administrative procedures are formulated by various competent agencies and included in different

8 Social Enterprises in Vietnam, Central Institute for Economic Management, 2019, p. 46, http://www.ciem.org.vn/Content/files/State $\% 20$ of $\% 20$ Social $\% 20$ Enterprise $\% 20 \mathrm{in} \% 20$ VN\%20Eng\%2001-04.pdf (accessed: 6.10.2019).

9 Vietnam cutting 50\% of business and administrative procedures: VCCI president, "Tuoi Tre News", http://tuoitrenews.vn/news/business/20181211/vietnam-cutting-50-of-business-and-administrative-procedures-vcci-president/48087.html (accessed: 6.10.2019).

10 Resolution No. 25/NQ-CP on Simplifying 258 administrative procedures under the management authorities of ministries, agencies.

11 Resolution No. 2/2019 ongoing implementation of major duties and measures to improve business environment and enhance national competitiveness by 2019 and vision to 2021, current situation review. 
legal documents such as status laws and substantive regulations. Administrative procedures consist of many types such as: (1) procedures on imposing administrative sanctions under Law on Handling Administrative Violations; (2) procedures on employing public officials under the Law on Public Servant and Cadre (2008); procedures on issuing permission for building construction under the Law on Construction (2014); procedures on issuing certificate of land use right under the Land Law (2013); procedures on issuing certificate of business registration under the Law on Enterprise (2014); procedures on issuing certificate of investment registration under the Law on Investment (2014) etc. In order to implement these status laws, Government, Ministries and Ministerial level agencies have issued a significant number of substantive documents (Decrees and Circulars) providing detailed procedures for implementation. Consequently, regulations on administrative procedures are inconsistent and overlapped and they cause many problems for individuals and organizations.

2. There is a lack of fundamental and comprehensive law on administrative procedures. The reform of administrative law is one of the key elements for building a transparent, accountable, strong, effective and efficient administrative system in Vietnam. Significantly, the 1992 Constitution (amended in 2001) was revised in 2013 in order to build a rule-of-law state and promote democratic society. In order to ensure a coherent, consistent, and comprehensive legal system, Vietnam has amended the key laws on organization and operation of administrative system such as Law on Organization of Government ${ }^{12}$ (2015); Law on Organization of Local government $(2015)^{13}$ as well as the laws on dealing with administrative litigations including Law on Complaints (2011) $)^{14}$ and Law on Administrative Lawsuits (2015). ${ }^{15}$ However, Vietnam still lacks comprehensive rules on administrative procedures, public service delivery, administrative contract, administrative decision which are considered as important laws to create an equal, open, favorable and transparent business environment. Since many administrative agencies including Government, Ministries, and local government have power to promulgate administrative procedures, therefore, administrative procedures are considered as barrier that preventing enterprises and individuals from executing their rights and obligations. Hence, the abolishment and reduction of unnecessary and complicated administrative procedures are an urgent task of government in 2017, for example, The Special Task Force of Ministry

12 National Assembly, Law on Government No. 76/2015/QH13, dated June 19, 2015.

13 National Assembly, Law on Organization of Local Government No. 77/2015/QH13, dated June 19, 2015.

14 National Assembly, Law on Complaints, No. 02/2011/QH13, dated November 11, 2011.

15 National Assembly, Law on Administrative Lawsuits, No. 93/2015/QH13, dated November 25,2015 . This law provides procedure for dealing with lawsuits under jurisdiction of the People's Court. It is different from Administrative Procedure Act of Japan. 
of Industry in 2017 and 2018 is set up to scrutinize all administrative procedures and the business conditions for simplification or abolishment. ${ }^{16}$

However, Vietnam does not have any Administrative Procedure Act like Japan, US or other countries. Administrative procedures are formulated by many competent agencies from central to local levels. APA of Japan provides administrative disposition with very clear process including public hearing as a compulsory procedure in adverse disposition. Contrary to Japan, public hearing is not compulsory procedures in adverse disposition in Vietnam. For example, Law on Handling Administrative Violations (2012) provides the explanation (public hearing) in the case of administrative sanction imposed from 15 million VNĐ for individuals or 30 million for organizations, or withdrawal of the rights to use licenses... However, it is not a compulsory procedure as under APA of Japan, Article 13 requires that administrative agencies shall establish procedure for hearing statements of subject parties of the adverse disposition. In addition, APA of Japan provides detailed process and time limits in administrative disposition which create consistent administrative procedures in all aspects of public administration.

Moreover, Vietnam also does not have any Law on licensing like some countries such as Law of Ukraine on licensing of certain types of economic activity. Therefore, each specialized status law as well as the guidelines for implementation (Decrees and Circulars) shall provide detailed conditions for issuing or depriving the right to use licenses in specific field of public administration. As a result, the license conditions are different in each area. Due to the lack of consistent administrative procedures in Vietnam, administrative agencies have more discretion in formulating administrative procedures for their fields of management, consequently there is a 'jungle of administrative procedures' in Vietnam. For example, during 5 months in 2019, Ministries and ministerial agencies cut off 3.425/6.191 administrative procedures related to business licenses. ${ }^{17}$

3. There is also a lack of effective mechanism on controlling administrative procedures in Vietnam. Currently, there is only Decree No. 63/2010/ND-CP (amended by Decree 92/2017) on controlling administrative procedures which defines the concept of administrative procedures, principles of promulgating and implementing administrative procedures. 'Control of administrative procedures means review, evaluation and monitoring conducted to ensure the feasibility of a regulation on administration procedures and satisfy the requirement of publicity and transparency in the process

${ }^{16}$ How does the Ministry of Industry and Commerce cut down the administrative procedures? http:// customsnews.vn/how-does-the-ministry-of-industry-and-commerce-cut-down-the-administrative-procedures-4400.html (accessed: 28.02.2018).

${ }_{17}$ Cắt Giảm Giấy Phép: Chính Phủ Yêu Cầu Nói Đi Đồi Với Làm, baodientu.chinhphu.vn http:// baochinhphu.vn/Kinh-te/Cat-giam-giay-phep-Chinh-phu-yeu-cau-noi-di-doi-voi-lam/370930. vgp (accessed: 6.10.2019). 
of implementing administrative procedures.' (Article 3.5) The controls of administrative procedures have been carried out not only in process of formulating legal normative documents but also in implementation process. The review of administrative procedures is the responsibility of ministries, ministerial agencies and local government. The review of administrative procedures mainly aims at simplifying administrative procedures. Decree No. 63 stipulates that: 'Administrative procedure review and evaluation must be carried out by ministries, ministerial-level agencies and People's Committees of provinces and centrally run cities and the Administrative Procedures Control Agency according to plan or under the instructions of the Government and the Prime Minister. Results of administrative procedure review and evaluation by these agencies serve as a basis for simplifying administrative procedures.' (Article 29.3)

In order to control administrative procedures, Prime Minister issued Decision No. 74/2010/QĐ-TTg to establish Administrative Procedures Control Agency (APCA) ${ }^{18}$ under Government Office in 2010. However, Decision No. 1668/QĐTTg of Prime Minister transferred APCA to Ministry of Justice since November 19, 2012. Notably, this organ was transferred back to Government Office since December 2016 under Decree No. 150/2016/ND-CP dated November 11, 2016 on defining the functions, tasks, powers and organizational structure of the Government Office. However, the limited capacity of APCA and its jurisdiction are the main challenges in reviewing and handling administrative procedures. APCA holds only power to conduct independent review and evaluation of administrative procedures in the following cases: (1) at the instruction of the Government or the Prime Minister; (2) if the administrative procedures are closely related and the result of implementation of an administrative procedure is the premise for the implementation of subsequent ones; (3) if the administrative procedures, through detection or feedbacks from individuals or organizations, are found cumbersome, difficult to implement, causing obstacles for production or business activities of economic organizations and people's lives (Decree No. 63/2010, Article 27.3).

Ministries and local government agencies shall decide to revise, supplement, replace, cancel or abolish its regulations within their respective competence or recommend it to competent agencies. APCA only carries out its reviews and recommend the competent agencies to revise, supplement or replace its regulations.

In addition, Supreme People's Court does not hold power to review administrative procedures prescribed by legal normative documents.

4. The National Database of Administrative Procedures has not yet developed the e-government application effectively in order to simplify administrative procedures

18 Decree No. 63/2010, Article 5: The Administrative Procedures Control Agency attached to the Government Office shall organize control of administrative procedures and manage the National Database of Administrative Procedures nationwide under this Decree. 
and buildone-stop-shop model. Online application for disposition has been applied in some provinces, especially since some big cities have introduced the smart-city model. ${ }^{19}$ However, the smart cities program requires to adapt modern technologies in administrative procedure such as online application for disposition. It also needs to develop internal collaboration among government sectors to provide public administrative services such as application for birth certificate, business registration... By doing so, Vietnam also needs to have legal grounds to use modern technologies in simplifying administrative procedures.

In progress of developing an accountable, transparent, strong, effective and efficient administrative system, Vietnam has promulgated a significant number of the status laws, especially after Constitution's amendment in 2013. Vietnam has developed two draft laws on general public administration and administrative decision since 2017. However, these drafts have been pending by National Assembly. ${ }^{20}$ In brief, complicated, non-transparent, and overlapped procedures are the major issues of administrative procedure in Vietnam. Significantly, the current legal frameworks on public administration still have many problems such as the lack of comprehensive regulations on general principles of public administration related to good governance, transparency, accountability of government. In other words, there is still a lack of the fundamental laws which provide a comprehensive, consistent provisions on principles, administrative procedures, administrative services delivery, administrative contract, administrative decisions, and judicial review. Therefore, the reform of administrative procedures is one of the most important tasks of Vietnam in building rule-of-law state.

\section{Solutions for developing comprehensive legal frameworks on administrative procedures}

Like the other developing countries in Asia, the promotion of the rule of law and legal reform are very important conditions to achieve the Millennium Development Goals in Vietnam. Globalization is influencing legal system of Asian countries. It requires each country to reform its legal system towards rule of law and good governance standards. Vietnam has been struggling to build a rule-of-law state.

19 Vietnam Active in Smart Cities, https://vneconomictimes.com/article/business/vietnam-active-in-smart-cities (accessed: 16.10.2019).

20 Understanding the needs of promulgating law on administrative procedures and administrative decision, there are two new draft law including Law on general public administration proposed by a member of National Assembly (2017); and Law on Administrative decision proposed by Government and Ministry of Justice has played a leading role in drafting this law (2016). 
Socialist rule-of-law state in Vietnam includes the following features: (1) state power belongs to people; (2) distribution of state power; (3) separation of party leading role and state management; (4) development of consistent and stable legal system: (5) effectiveness of law in administration; (6) equal legal protection; (7) and the independence of the judicial system. ${ }^{21}$ Vietnam has reformed the institutions and laws in line with international standards. For example, Vietnam became a member of the UN Convention Against Corruption in 2009 with strong commitment in corruption control, especially in executive branch.

In order to narrow the gaps of domestic law to meet the rule of law and good governance standards, Vietnam has carried out legal reform, especially the Constitutional Law and Administrative Law reform. Constitutional Law shall focus on the constitutional review mechanism and distribution of powers and the Administrative Law shall focus on institutions, mechanism for controlling discretion including administrative disputes, transparent and accountable institutions.

It is evidenced that the amendment of Constitution in 2013 provides clearly the distribution of powers among three branches: legislative, executive and judicial power. In addition, Vietnam are attempting to use the laws and institutions to promote economic development. ${ }^{22}$ However, Vietnam Competitiveness ranked at 67 in among 140 countries with 61.4/100 points in 2018. ${ }^{23}$ The Constitution adopts a new tool of the vote of confidence for legislators to challenge members of Government since 2001. In addition, administrative reform master plan 2011-2020 emphasizes the need to build an accountable and transparent system to prevent corruption. The abuse of state power is considered as one of the challenge for Vietnam in building rule-of-law state. Therefore, control of administrative organs discretion is the most important task of Vietnam.

Competent administrative organ and person have discretion in interpreting the legal regulations applying for specific cases. 'Administrator has secured extensive powers, of granting, revoking and refusing licenses, of rule-making, inquiry, inspection, investigation seizure, supervision, etc., leading to affect and control the rights, liberty and freedom of the individual in society. ${ }^{24}$ Consequently, public official may infringe on the rights and legitimate interests of citizens when exercising his/ her power. It is essential to control discretion of public officials in decision-making process to prevent public officials from abusing of state power. Administrative pro-

21 Hongyi Chen, Constitutionalism in Asia in the Early Twenty-First Century, Cambridge University Press, Cambridge 2014, p. 198.

22 J.S. Gillespie, Transplanting Commercial Law Reform: Developing a "rule of Law" in Vietnam, Ashgate Publishing, Ltd., Aldershot 2006, p. 1.

${ }_{23}$ Vietnam Competitiveness Index, https://tradingeconomics.com/vietnam/competitiveness-index (accessed: 21.10.2019).

24 P. Hemalatha Devi, Administrative Discretion and Judicial Review, Mittal Publications, New Delhi 1994, pp. 45, 46. 
cedure is a process of exercising executive powers of administrative organ or competent person in response to the request of individual or organization or applying enforcement measures. There is a high possibility of abuse of state's power if there is unclear process of exercising state's powers. Therefore, law on administrative procedures plays a significant role in controlling discretion and preventing public officials from abusing state powers, infringing the rights and legitimates interest of individuals. Obviously, all administrative decisions or acts made by authorities must comply with the laws. However, Vietnam still lacks comprehensive legal framework on administrative procedures, as a result, the abuse of state's power, corruption and infringement of the rights and legitimate interests of citizens or organizations remain crucial issues in Vietnam.

Vietnam should focus on following activities to build rule-of-law state and achieve the MDGs.

Firstly, it is essential to develop a Law on Administrative Procedure as Japan to provide clearly the steps of disposition (disposition upon application and adverse disposition) and the definition of legal terms including administrative order, notice, and guidance. Currently, public hearing and public participant is not compulsory in decision-making process. Authorities are not liable for unreasonable decision because individual/organization can only complaint or initiate administrative case on the legal grounds of unlawful decision/act infringing their rights and legitimate interest. In addition, currently, the Decree on controlling administrative procedure is the only fundamental legal framework and the Administrative Procedure Control Office (under Government Office) has power to review all administrative procedures. Hence, Vietnam lacks the fundamental regulations on principles and steps for making administrative procedures. Therefore, this law will play an important role in ensuring a transparency and accountability of government. In order to prevent authorities from abusing state's powers, Vietnam should follow the experience of Japan in developing an Administrative Procedure Act which includes the key principles for disposition. ${ }^{25}$ The APA of Japan firstly divides disposition into two types with detailed processes. Especially, regulations on review standards and public hearing are good examples for Vietnam because these provisions will create more accountable and transparent public administration system. Public officials must follow the standards in process of decision - making as well as enable the subject of decision to take part in decision - making process. Consequently, it also minimizes the number of administrative litigations.

Secondly, it is essential to establish an independent mechanism for constitutional review. This mechanism ensures the consistency of legal system. Currently, only Standing Committee of the National Assembly has power to interpret and review the laws. In addition, Ministry of Justice has power to review legal normative

25 Administrative Procedure Act of Japan, No. 88, 1993. 
documents and Supreme Court can only recommend the competent agencies to review the legality and constitutionality of legal normative documents. However, there are many state organs which have power to promulgate legal normative documents in order to provide the guideline for implementation, especially the Government and Ministries. Hence, inconsistency and unconstitutionality remain the key issues of legal system in Vietnam in general, and administrative law.

Thirdly, Vietnam needs to promote the quality of the public participation in decision-making process. Law on Promulgation of Legal Normative Document (2015) stipulates the compulsory procedures for public participation and regulation impact assessment (RIA). The competent agencies do not bear any responsibility in responding to public comments. The quality of draft law depends on the drafting members who are often public officials of ministries (executive organs) whereas National Assembly lacks capacity in legislation. Hence, the quality of draft law can be improved when public comments are strengthened.

Fourthly, the promotion of privatization is essential to change the role of government in delivery of public services. Although, Vietnam has carried out the privatization of the SOEs, there are still many challenges to overcome. Citizens are still facing difficulties in accessing the quality public services such as healthcare and education, public infrastructure... Therefore, engaging private sectors in delivery of public services and controlling the quality of public services are crucial to ensure the fundamental human rights of citizens. Vietnam should create a transparent, fair, and competitive environment for private sectors in providing public services.

Fifthly, promotion of the E-Government is also essential for Vietnam to reform the administrative procedures. Modern technology shall be utilized to enable citizens and organization to have the access to information, online application system. E-Government can simplify the administrative procedure, reduce the costs of implementation, and ensure quick response to the request of citizens and organizations. Vietnam currently has established the public administrative center in each province as the hub for delivery of administrative services to citizens and business sectors. It is a one-stop-shop model combining different specialized departments in one public administrative center. This model creates an interorganizational collaboration mechanism to provide administrative services for organizations and individuals (disposition upon application). Therefore, development of the national plan (financial and human resources, technology) as well as legal framework for E-Government is crucial to reform administrative procedures in Vietnam.

In brief, the rule-of-law state is required to ensure compliance with the binding law of all administrative organs and competent persons. Administrative procedure is the process of exercising state's powers of competent person and administrative organ as well as ensuring compliance with the binding laws. If the process is transparent and simple and ensures public participation in decision-making process, government can control corruption and abuse of state's power. Administra- 
tive organ and its competent persons have discretion in decision-making process, therefore, this discretion must be supervised through development of the specific review standards for disposition upon application and adverse disposition. Hence, development of the comprehensive legal framework on administrative procedures is one of the key factors for Vietnam to progress in building the rule-of-law state.

\title{
STRESZCZENIE
}

\section{REFORMY POSTECPOWANIA ADMINISTRACYJNEGO REALIZUJĄCE ZASADE PAŃSTWA PRAWA W WIETNAMIE}

\begin{abstract}
Zmiana z gospodarki centralnie planowanej na socjalistyczną gospodarkę rynkową była punktem zwrotnym w Wietnamie. Wraz z ogłoszeniem Konstytucji z 1992 r., która zastąpiła wcześniejszą Konstytucję z 1980 r., wprowadzająca model socjalistyczny, w Wietnamie zaczęła się reforma systemu prawnego, mająca na celu lepsze reagowanie na sytuację społeczno-gospodarczą w państwie. Co istotne, zasady państwa prawa i prawa człowieka zostały uregulowane w Konstytucji z 2013 r. Od lat 90. Wietnam zrobił olbrzymi krok w zakresie reform przepisów administracyjnych, która miała na celu zbudowanie przejrzystego, silnego i odpowiedzialnego rządu. Nadużywanie władzy państwowej i korupcja wciąż stanowią jednak przeszkodę dla obywateli i dla prowadzenia biznesu w Wietnamie. Wietnam po przystapieniu do Światowej Organizacji Handlu (WTO) mocno zaangażował się w opracowanie niezależnego mechanizmu rozstrzygania sporów administracyjnych poprzez zmianę ustawy o skargach administracyjnych z 2011 r., która zastąpiła ustawa o postępowaniu administracyjnym z 2015 r. Jednak liczba skarg administracyjnych pozostaje bardzo wysoka i sięga około 27 tys. spraw rocznie. Pozostaje pytanie, jaka jest recepta dla Wietnamu na walkę z korupcją i nadużyciami władzy w rządzie. W niniejszym artykule zwrócono uwagę na potrzebę reformy prawa administracyjnego jako kluczowy czynnik budowania odpowiedzialnego i przejrzystego rządu opierającego się na zasadzie państwa prawa w Wietnamie.
\end{abstract}

